$10-1-1996$

\title{
To Blood Sacrifice and the Nation: Revisiting Civil Religion
}

Carolyn Marvin

University of Pennsylvania, cmarvin@asc.upenn.edu

David W. Ingle

Follow this and additional works at: https://repository.upenn.edu/asc_papers

Part of the Communication Commons

\section{Recommended Citation}

Marvin, C., \& Ingle, D. W. (1996). To Blood Sacrifice and the Nation: Revisiting Civil Religion. Journal of the American Academy of Religion, 64 (4), 767-780. https://doi.org/10.1093/jaarel/LXIV.4.767 


\section{To Blood Sacrifice and the Nation: Revisiting Civil Religion}

\section{Disciplines}

Communication | Social and Behavioral Sciences 


\title{
To Blood Sacrifice and the Nation: Revisiting Civil Religion
}

\author{
Carolyn Marvin and David W. Ingle
}

Americans live in a culture that is as religious as any that exists. In this article we contend that nationalism is the most powerful religion in the United States, and perhaps in many other countries. ${ }^{1}$ Structurally speaking, nationalism mirrors sectarian systems of belief such as Christianity, Judaism, Islam and others that are more conventionally labeled as religious. It happens that nationalism also satisfies some of the most traditional definitions of religion, but citizens of nation-states have religious reasons for denying it. We argue that both sectarian and national religions organize killing energy by commuting devotees to sacrifice themselves to the group. We also briefly explore the ritual role of media in propagating national religion. Media are not the most important ritual vehicles for nationalism, but they matter. Though based in empirical observation, our claims are theoretical in nature. ${ }^{2}$ Their value lies in rethinking certain empirical phenomena in relation to notions of nationalism and religion in the contemporary world. Our examples come mostly from the United States and its majority sectarian faith. Although generalization is risky, the principles we describe are broadly applicable to other enduring groups, defined as those for which members are willing to give their lives.

By "religion" we mean a system of cosmological propositions grounded in a belief in a transcendent power expressed through a cult of divine being and giving rise to a set of ethical prescriptions. ${ }^{3}$ In the moral world shared by many readers, these prescriptions deplore violence and regard any use of it as prima facie profane. Where religious devotees unapologetically embrace violence, the faiths to which they subscribe may be considered morally flawed. Alternatively, it may be claimed that practitioners of violence who act in the name of religion have mistaken the true prescriptions of their faith. The familiar claim that a religious view of the world is characterized by a moral opposition to violence ignores a more complex reality in which faiths that most deeply bind the commitment of devotees are structures for organizing killing energy. This is true both for religions that aggressively kill the other in the name of a deity or deities and those that pledge their devotees to self-sacrifice when confronted with violence. We shall argue that violent and so-called non-violent religions are structurally indistinguishable from a certain perspective.

To equate nationalism and sectarianism unsettles champions of both Champions of nationalism see sectarianism as dangerous to nationalism's healthiest aspirations. Sectarianism, they fear, introduces passions that may manifest themselves in violence. They wish to separate church and state by subordinating the claims of the former to the latter Champions of sectarianism see nationalism as threatening to religious values, especially non-violence. The state, they say, is profane because it engages in violence. They wish to bend state claims to fundamental sectarian precepts. ${ }^{4}$ Perhaps nationalism and sectarianism recognize something about each other that they hesitate to recognize about themselves. Each fears that members of the other community are willing to kill and die for truth as they understand it. For what is really true in any community is what its members can agree is worth killing for, or what they can be compelled to sacrifice their lives for. The sacred is thus easily recognized. It is that set of beliefs and persons for which we ought to shed our own blood, if necessary, when there is a serious threat. Rituals that celebrate this blood sacrifice give expression and witness to faith. Sacrificial death thus defines both sectarian and national identity. This is the first sense in which both are species of religion.

On the whole, we misunderstand the genuinely religious character of American patriotism and the violent character of genuine religion. What distinguishes nationalism from sectarianism is not group logic, for both are religions of blood sacrifice. What distinguishes them is historical location. In the West Christianity once could kill and ask others to die in the name of its particular god. In some places it does this still. But in general in the West the power to compel believers to die passed from Christianity to the nation-state, where it largely remains. Christianity has no authorized guns within the boundaries of the United States, nor does any other denominational sect. In our religiously pluralist society sectarian faith is optional for citizens, as everyone knows. Though denominations are permitted to exist, they are not permitted to kill, for they are not officially true, which is a way of suggesting they are false. Only the true 
god, whose agent is the nation-state, may kill. The state allows whoever accepts these terms to exist, to pursue their own beliefs, and to call themselves what they like in the process. But only the deity may kill our own. Whoever competes with the true god, the nation-state, may be punished at the cost of his life. This was the fate of David Koresh, the leader of the ill-fated Branch Davidians in Waco, Texas, for exercising killing power that not only belongs to the national god exclusively but defines him. In civil religious terms David Koresh's sin was blasphemy.

Americans traditionally regard the nation-state as the domain of unassailable force and religion as the domain of unassailable truth. This separation of faith and force is markedly unstable and collapses completely in wartime. Elsewhere, the more usual arrangement has been strongly forged links between spiritual and political power. This is because the only religion that can truly deliver the goods must have visible agency, worldly power. Jesus' disciples felt it, and a Weberian Protestant ethic suggests it. Wherever religion is fervently embraced, it follows in the minds of many believers that it is entitled to glory in missions of conquest that reflect God's will. Islam did this for centuries before European monarchies accomplished it for Christianity. And though religions have long survived and flourished in persecution and powerlessness, supplicants nevertheless take manifestations of power as blessed evidence of the truth of faith.

If nationalism is religious, why do we deny it? Because what is obligatory for group members must be separated, as holy things are, from what is contestable. To concede that nationalism is a religion is to expose it to challenge, to make it just the same as sectarian religion. By explicitly denying that our national symbols and duties are sacred, we shield them from competition with sectarian symbols. In so doing, we embrace the ancient command not to speak the sacred, ineffable name of god. That god is inexpressible, unsayable, unknowable, beyond language. But that god may not be refused when it calls for sacrifice.

Among the handful of theorists who have seriously examined the religious character of American nationalism is Carlton Hayes, who argued that Western nationalism adapted many features of Christianity, in the shadow of which it first appeared. Citizens are born into the nation-state, Hayes observed, just as supplicants once were born into the Church. They have no choice but to be citizens, just as medieval Christians were compelled to embrace the faith of their birth. The social geographer Wilbur Zelinsky observes that the contemporary American flag has a visual power and presence for its believers that is comparable to the medieval crucifix (243). We agree. The flag in high patriotic ritual is treated with an awe and deference that marks it as the sacred object of the religion of patriotism. The flag is the skin of the totem ancestor held high. It represents the sacrificed bodies of its devotees just as the cross, the sacred object of Christianity, represents the body sacrificed to a Christian god.

The soldier carries his flag into battle as a sign of his willingness to die, just as Jesus earned his cross to show his willingness to die. Both the cross and the flag mark the border, the transformative point at which the believer crosses over into death. In both Christianity and nationalism the violently sacrificed body becomes the god renewed - in Durkheimian terms, the transformed totem. In Christianity the revivified totem is the risen Christ. In American nationalism the transformed totem is the soldier resurrected in the raised flag. On the basis of his sacrifice the nation is rejuvenated. As the embodiment of sacrifice, the flag has transforming power. Certain acts cannot be performed except in its presence. Elaborate rules govern what may touch it and how devotees must behave in its presence. It must be kept whole and perfect, as holy things are, and ceremonially disposed of when it is no longer fit to perform the functions of the totem object.

Some citizens openly speak of the American flag as sacred. Can we disregard the impassioned testimony of others that it is not, and neither is the nation it represents? The answer lies in the ritual gestures that surround the flag. Roy Rappaport distinguishes ritual gesture from language, which is always other than that which it signifies. By contrast, gestures express what cannot be denied. What counts for the survival of the group is what we will do in public on its behalf while congregants bear witness. This is what the survival of the group requires: that we publicly execute our obligations. The sanctity of national symbols is protected by treating them gesturally as sacred, even when we insist in 
language that they are not. And when the god commands it, we must perform the ritual sacrifice, war, that sustains the group.

To understand how war is ritual sacrifice, recall that the raw material of society is bodies. Organizing and disposing of them is the fundamental task of all societies. The social is quite literally constructed from the body and from specific bodies that are dedicated and used up for the purpose. The enduringness of any group depends at least partly on the willingness of us members to sacrifice themselves for the continuing life of the group. The creation of national or sectarian religious sentiment depends on a common secret, which is that the underlying cost of all society is the violent death of some portion of its members. There is more. Our deepest secret, the collective group taboo, is the knowledge that society depends on the death of this sacrificial group at the hands of the group itself. This is the totem principle concretized. According to Durkheim, the group becomes a group by agreeing not to disagree about the group-making principle. On what understanding of the group is this pact made? Durkheim never answered this question directly. Our answer is that the principle by which the group constitutes itself is manifest in collective victimage.

Why is it necessary to kill our own, and why can't we admit it? It is necessary, and we cannot admit it because violence poses the greatest threat to the group from within as well as without. It is never eradicated. Like sex, it can only be channeled. When violence starts, it can be prevented from spreading only if someone is willing to submit. Submission is the sacrificial principle. To keep violence from escalating and killing every member of the group, either by invasion from without or contagion within, group members agree to submit to a violent authority that punishes all who do not honor the totem's exclusive right to kill its own ${ }^{5}$. Even when the enemy kills us, his transgression is not so much that he kills as that he kills us. Only totem authority - the group deity in sectarian terms, the group itself in Durkheimian terms - is so entitled.

If the totem may kill us, we are all at risk and all killers. This knowledge must be set apart from the group, for it suggests the frailty of group cohesion. We use the term taboo to describe the tension between the violent sacrificial mechanism that sustains enduring groups and the reluctance of group members to accept responsibility for enacting it. To protect themselves from acknowledging the source of group unity, citizens render totem violence and its symbols sacred. The knowledge that the group must sacrifice its own to survive is a secret. We keep it by treating violence as primitive and morally suspect, a failure of social structure rather than an elemental component ${ }^{6}$. Where violence exists, it is presented as a last resort, a challenge to civilized modernity as the hallmark of the nation-state. Thus, we avoid acknowledging in a thousand ways the true nature and object of totem power.

For example, we tell ourselves that the purpose of war is to kill the enemy. And it is. But what keeps the group together and makes us feel unified is not the sacrifice of the enemy but the sacrifice of our own. If the ritual purpose of war were merely to kill the enemy, the deaths of some 40,000 or more Iraqis would have made a lasting contribution to American national unity. During the Persian Gulf war, notable for the ephemerality of its unifying effect, only 147 Americans died, a poor totem sacrifice. The two most unifying bloodlettings in American history, the Civil War and World War II, sacrificed the largest number of the nation's own, both absolutely and in proportion to the total population. We construct our identity from the flesh and blood of group members. All enduring groups, national or otherwise, rely on this sacrificial identity.

The doctrine that provides the central experience of Christian faith is the sacrifice of an irreplaceable son by an all-powerful father whose will it was that the son should die violently. Ritually speaking, the sacrificial promise is that the father's desire for blood revenge against those who offend his power will be satisfied for all time by this execution. Because history begins anew with this sacrifice, there need never be another. It has not turned out that way. The measure of the Christian believer's devotion to the faith remains his willingness to do as Jesus did and sacrifice himself. Willingness to sacrifice oneself, the ultimate sign of faith in social existence, is also the sign of the patriot, the proven and true member of the nation-group. We declare that we don't want death, that only the most compelling need justifies the death of our own. (And this is true. The compelling need is the survival of the group). Through successful sacrifice, internal hostilities are discharged, the group is unified. Then the cycle 
begins again. Those who worship the son who died at the heavenly father's command revere the totem principle, that only our own god has the right to kill our own, just as surely as those who revere the soldier son, who dies at the command of patriarchal generals.

In both sectarian and national religion the son's willing sacrifice is much admired, while the father's decision to sacrifice him is hidden. To say that Christians worship a violent father who sacrificed his own son may appear blasphemous to believers. The claim articulates the unspeakable totem principle. During the 1992 presidential campaign, for example, talk centered around whether the son, Bill Clinton, was a good son or not for refusing to submit to sacrifice in Vietnam. The discussion was never about whether George Bush had been a good father to send the sons to a bad war. That taboo discussion suggests the sense in which religions that counsel non-violence as a strategy are indistinguishable from those that do not. Both counsel the willing sacrifice of their followers to violence. Both are willing that devotees should die to demonstrate the viability and integrity of the totem principle that only their own god has the right to kill their own. Both understand that violence will not stop until someone is willing to submit. In the case of American nationalism, that god is the group symbolized in the totem fetish, the flag, and embodied in the totem leader, the President.

The claim that violence, and only violence, produces enduring group unity is at odds with arguments that enlightened modern nations maintain order not chiefly by force but by other means. These include social pressure implemented by surveillance, a claim identified with Anthony Giddens, and a sense of group identity fostered by collective textual imagination, a notion championed by Benedict Anderson. To speak briefly to each surveillance without coercion would be toothless. Where surveillance compels response, its targets explicitly or implicitly recognize the physical force behind it. Second, not textual communities but communities of blood unite their members sacrificially. The holiest religious holidays do not celebrate literature but blood symbolically framed as birth or death. Texts may describe blood sacrifice and may be useful instruments in the formation of national consciousness for that reason. But textual communities do not physically fight for their members. Only communities bound by blood do this.

What precipitates the large-scale ritual sacrifice we call war? Totem crisis, a term we adapt from Rene Girard's notion of sacrificial crisis, sets it in motion (39-67). A totem crisis occurs when there is uncertainty about the essential borders that demarcate our group. When territorial borders are breached and no longer differentiate Us from Them, there may be a totem crisis. Or there may be uncertainty because persons inside or outside the territorial border usurp the prerogative of the totem god and kill our own. In both conditions totem legitimacy is re-established only by sacrificing our own - in the successful case, enough of us to make an offering of real value Sacrifice restores totem authority and reconsolidates the group. This is why we die for the flag and commit our children to do so. To resolve totem crisis, the totem must re-create its exclusive killing authority out of the very flesh of its members. Blood is the group bond Blood sacrifice at the border, or war, is the holiest ritual of the nation-state ${ }^{7}$.

To admit that we kill our own is unacceptable, for if there is not shared agreement about who will be sacrificed, violence may become chaotic instead of ordered; the group may be destroyed. To keep the sacrificial secret, an acceptable pretext to slaughter group members must be created. What Girard calls the ritual victim constitutes this pretext. In the nation-group context, this is the enemy. In addition to a ritual victim, a second or surrogate victim must stand in for members of our group against whom we have real grievances ${ }^{8}$. As a group we agree to kill members of a surrogate-victim sacrificial class expressly created for the purpose. Upon it we displace our anger at other members of our group. The ritual victim gives us an acceptable reason to kill our own. The surrogate victim is constituted in the portion of our group that we kill. The priestly class that trains for sacrifice at the hands of the nation-group is the military. Soldiers live apart in monastic orders that discipline and purify themselves for ultimate sacrifice. The knowledge that the true object of sacrificial violence is ourselves is separated from devotees, as sacred things are, whenever it threatens to surface explicitly.

What does successful ritual sacrifice accomplish? After enough bloodletting, the slate of internal hostilities is wiped clean. The group begins again. The external threat is met. Our bad feelings toward one another are purged. Time begins anew, space is re-consecrated. The group basks for a while in the 
unanimity of its effort, until internal hostilities accumulate once more, and the entire cycle must be repeated. Thus, what constitutes the nation in any moment is the memory of the last successful blood sacrifice that counts for living group members. In the United States this is World War II, fast receding in its effect as a national unifier as those who carry its body memory become a smaller and smaller proportion of the population. Lacking that memory, we must search for new sacrifices, while agonizing over our internal disunity.

Not all wars are successful blood sacrifice rituals. Some imperil rather than consolidate the group bond. Blood sacrifice rituals that give rise to enduring unity within the group must satisfy the following conditions. Since most do not, their success is qualified to that extent

1. Blood sacrifice must touch or seem to touch every member of the group. It must be large enough for group members to recognize the cost to the group and to feel the pain of loss at a personal level.

2. The sacrifice must be willing. Unwilling sacrifices may be reconstructed in death as having been willing, but the most useful sacrifice to the group declares in advance of leaving that he faces death willingly. Thus we say that soldiers "gave" their lives for the country.

3. Victimage must be unanimous. This means that war must be popular. The entire group must collude in the secret that group unity comes from killing our own. Thus, Vietnam was not a successful ritual sacrifice. The totem secret could not be kept.

4. Only undertakings that pose a serious risk to group survival have magical force for believers. At the outset the outcome of ritual effort must be genuinely uncertain. Great ritual uncertainty requires the most potent magic, which is blood. Of the 1944 Normandy invasion, an American journalist recalled, "The moment of the invasion was a great and solemn moment, it was a prayerful time. Because one didn't know. And everything was at stake, everything "9 "When I think of the beaches of Normandy choked with the flower of American and British youth," Churchill told Eisenhower before the assault, "and when in my mind's eye I see the tides running red with their blood, I have my doubts I have my doubts "10

5. Win or lose, the outcome of ritual effort must be clear and definite. Time and space must be redefined. History begins from this moment, territorial borders are re-created or reaffirmed. Time and space are consecrated anew, as if for the first time. This moment becomes the new beginning of the group, as World War II was for the generation of Americans now passing from the scene.

6. Only another ritual can repair a failed ritual. It could be argued, for example, that the ritual failure of the Vietnam War precipitated the sacrifice of Richard Nixon as a sitting president in the Watergate scandal that resulted in his resignation.

\section{Media Ritual}

All important things in society are ritualized. The prototype ritual of nation-state cohesion is popular war, though other rituals count. These include presidential elections, sending soldiers off to war, and welcoming them home again. These rituals also organize and express group identity, but blood sacrifice is the most potent. This is because it is body transforming. In the system of nationalism mass media perform the same functions that sacred and priestly texts perform in other religious systems. They recall central moments of group identity, rehearse ritual and mythic structures for believers, and pull from the flux of daily life what is grist for the mill of religious nationalism. The view that media are a reduced or corrupted ritual form is mistaken insofar as this is a claim that media rituals have replaced, badly, something else. The something else is blood sacrifice, the central rite of nation-groups. Media are instrumental in reporting blood sacrifice and assembling congregations. Congregants acquire knowledge of group threats and sacrificial occasions, and are socialized into the proper execution of ritual forms by media. Nationalism is the religion, among the vehicles available to ritualize it are media. Our central points about ritual as it pertains to nationalism are these 
1. The purpose of ritual is to sustain the group by repeating (at various levels of intensity) the act of group creation. A successful ritual stops time at the perfect creation moment. It repeats and freezes the retrospectively golden moment when the group was created out of sacrifice. In this moment the debt to the bloodthirsty god was paid. The group was pristine. This was the moment when sacrifice was truly enough, when we were delivered from time and death.

2. Rituals may be contrived or opportunistic. The most powerful rituals of nation-group solidarity are opportunistic responses, such as war, to group threat. But opportunistic rituals are unpredictable in their occurrence and expensive in their prosecution. Their magic is great precisely because they are risky and costly. Contrived or pre-planned seasonal rituals fill in the intervals between opportunistic groupforging rituals by rehearsing the drama of sacrifice and regeneration. American presidential elections are prototypic contrived rituals of sacrifice and regeneration.

3. Rituals have two major dynamics. They create the world by transforming chaos into cosmos, to use Mircea Eliade's terms, or they remodel and recall the transformation of chaos into cosmos. All rituals model and transform to one degree or another, but rituals may be classified by whether they are primarily transforming or commemorative. On the principle that the social is constructed out of the body, the most powerful rituals transform bodies directly. In relation to them media rituals are representational and commemorative. They do not have the power of blood sacrifice, but they do have a critical function. They re-present blood sacrifice that has occurred or is occurring and scan the environment for events that lend themselves to future blood sacrifice. Media preoccupation with violence speaks to their role in the ritual system of blood sacrifice. We stay in shape as a group by imposing ritual form on events of the world, large and small, as they offer themselves. Thus media constantly rehearse the structure of sacrifice and its supporting myths. Ritualized events focus group attention on threats to solidarity and help set in motion resolving rituals that work more or less well. In this way devotees ritually refurbish group solidarity and wait for the peculiar mix of events that signal more serious group threats.

\section{THE RABIN ASSASSINATION}

The organizing structures that interest us are exclusive neither to the United States nor Christianity. They are totemic. The representation of national blood sacrifice in totem terms was visible on Israeli television following the assassination of Israeli Prime Minister Yitzhak Rabin in November, 1995. We will briefly address some of its features. In the greater vulnerability of Israel's territorial boundaries and the loss of a traditional ritual enemy the Oslo peace accords posed a genuine totem crisis for Israelis. In the period leading up to Rabin's assassination that peril was ritually expressed in angry images of dissent portraying the Prime Minister in Palestinian headdress and, alternatively, in SS uniform Protest that blurred distinctions among group members and their historic enemies conveyed dissenters' belief that traditional group boundaries and definitions were at risk. A vulnerable group may precipitate the sacrifice of a group leader who has staked his all on embodying it, though this sacrifice may take many forms besides assassination, including electoral defeat ${ }^{11}$. The bloody assassination of Rabin instantly became a ritual focus for renewing national unity and shoring up the group's sense of itself through demonstrations of collective rededication to the idea for which Rabin was assassinated.

Would the incremental unity achieved by the blood sacrifice of Yitzhak Rabin endure? The assassination was not a popular war in which the blood sacrifice of soldiers directly touches many families. But, as Prime Minister, Rabin had a para-family relationship to every member of the group. He was a willing sacrifice just as a soldier is, and for the same reason. As the most exalted member of the totem class, his job was to bear the burdens of the group and sacrifice himself to it when called to do so. Within hours of the assassination Acting Prime Minister Shimon Peres appeared on television to assure group members that the sacrifice had been willing. On the last day of his life, said Peres, the usually dour Prime Minister had been happy and serene. He had met his fate willingly.

A prominent element in the ritual re-presentation of the assassination was the lyric sheet for a peace song sung by the Prime Minister moments before his death. Blood from the fatal wounds soaked the lyric sheet. The story of this relic was endlessly repeated in media and recounted at the funeral by 
Rabin's closest aide, who displayed it for devotees. It performed the same ritual function as the flag soaked in battlefield blood of American sacrificial myth. Both embody the spirit of the soldier sacrificed for the group idea, in this case, peace with Israel's neighbors.

But the sacrifice was imperfect. Rabin's assassination was not unanimous victimage. Though his death may have been the real or fantasized wish of many group members, it was not the articulated resolve of the group, as in a popular war in which citizens are moved to declare that they offer their children for sacrifice. Imperfect sacrifice risks exposing the totem secret. The knowledge that the group cannibalizes itself to survive is group-threatening. Seven months after the assassination, Israelis overturned the labor government that had cast itself as inheriting Rabin's policies. They did so uncertainly. Less than a single per cent of the vote separated the two major candidates. The sacrifice of Rabin, followed by a series of suicide bombings whose casualties were enough to imperil totem unity but not enough for full-scale war, left the country muddled and searching for a unifying vision. In totem terms the prognostication was that more sacrifice would be needed before a defining sacrifice could be declared.

\section{Conclusion}

Cohesion in enduring groups is accomplished within a framework of violence as a structural rather than contingent social force, religion as the truth that we are willing to die for, and the representation of society to itself through blood sacrifice rituals performed on the bodies of supplicants. The most powerful expression of this religious framework in the United States, and not only there, is nationalism. On the surface, we deny nationalism's religious attributes and functions in order to keep the killing authority of the group from being challenged by sectarian faiths that have been stripped of the power to sacrifice the lives of devotees. When these faiths or others challenge totem power, a totem that wishes to endure must fend them off decisively. This means by killing its own, if necessary. If it does not act, a new enforcer may overthrow it.

Our analysis is not a brief in favor of violence or against it. It is an argument about the role of violence in organizing and maintaining enduring groups. It is clear that human beings suffer greatly from violence. The practice of non-violence does not avoid suffering or end violence, it redistributes both. Answering violence with non-violence may be no less painful and destructive in its effects on individuals and groups. Similarly, benefits may accompany either violence or non-violence in group unity and survival. It may be troubling to realize that there are no absolute formulas for achieving peace and goodness, such as total reliance on the precept never to act violently. In the language of sectarian religion, our dilemma is that we are never without sin, which is to say, violence, even when we give up our own bodies, or our children's, to the violence of others. The traditional esteem in which we hold nonviolent sacrifice to the forces of violence is misleading to this extent conventional interpretations of non-violence obscure and conceal the violent authority that demands sacrifice and perpetrates violence against supplicants or their perceived enemies, even when both parties offer themselves willingly. We are meant not to notice. The secret keeps us together.

\section{Note:}

Carolyn Marvin is an Associate Professor at the Annenberg School for Communication at the University of Pennsylvania, Philadelphia, PA 19104. David W Ingle is a doctoral candidate in clinical psychology at Widener University, Chester, PA 19013

This article is based on our forthcoming book, Capturing the Flag The Symbolic Structure of Nationalism. The authors gratefully thank Martin E Marty for comments on an earlier version delivered as a plenary session at the "Conference on Media, Religion and Culture," sponsored by the Lilly Endowment and the World Association for Christian Communication, at the University of Colorado at Boulder, Jan 11-14, 1996. The authors also thank David Park for unstinting assistance in preparing the manuscript.

'Some years ago Robert Bellah and his colleagues began an important debate by classifying American patriotism as a civil religion. See Robert $\mathrm{N}$ Bellah, "The American Civil Religion," Daedalus 96 (Winter 1967) 1-21, and Robert N Bellah and Phillip E Hammond, eds, Varieties of Civil Religion (San Francisco Harper \& Row, 1980) On the history of the American civil religion debate, see George A Kelly, "Civil Religion," in Politics and Religious Consciousness m America (New Brunswick, NJ Transaction, Inc , 1984) 209-246 
${ }^{3}$ A typical definition appears in Stephen Carter's The Culture of Disbelief (New York Basic Books, 1993$) 17$ "When 1 refer to religion, 1 will have in mind a tradition of group worship (as against individual metaphysic) that presupposes the existence of a sentience beyond the human and capable of acting outside of the observed principles and limits of natural science, and, further, a tradition that makes demands of some kind on its adherents"

${ }^{4}$ Consider the modified Pledge of Allegiance recited by Christian conservatives at the National Affairs Briefing, held in Memphis January 19-20, 1996, to rally the troops for the 1996 presidential election. "I pledge allegiance to the Christian flag and to the Saviour for whose Kingdom its stands" Quoted in Gustav Niebuhr, "God's Will and Political Will Top a Conservative Agenda," New York Times, Jan 22,1996 A12

${ }^{5}$ This is the authority that the English jurist William Blackstone called "supreme, irresistible, absolute, uncontrolled authority" Quoted in Daniel Lazare, "The Lords of Misrule," New York Times, Dec 27, 1995 A15

${ }^{6}$ Commenting recently on the need for NATO authority to contain warring factions in the Balkans, the historian Donald Kagan appealed to totem principles while denying them, as follows "The cnti-

${ }^{7}$ Even if we grant that sacrificial mechanisms organize group identity, what view of the world permits us to regard this organization as religious. Those who reject the actuality of civil religion have done so on the grounds that American patriotism makes scant appeal to a supernatural metaphysics. They define religion as an explanatory system based in a cult of divine beings. The point of contention between those for whom civil religion usefully describes patriotic practices and those for whom it does not is the definition of the sacred. We contend that the doctrines and ceremonies of nationalism clearly reference the sacred. The divine beings invoked by national rituals are the dead totem fathers embodied in the flag. But this is not the only religious test a civil religion of patriotism satisfies George Kelly proposes that religion is 1) a justification and consolation for the most wrenching human tragedies, especially mortality, 2) a guide to one's dignity of place and meaning in the cosmos, especially in view of personal inadequacy and the need of expiation, and 3) a primary bond of social cohesion expressed in rituals or ceremonies that connect human beings to each other and the sacred. See Politics and Religious Consciousness in America (New Brunswick, NJ Transaction Books, 1984 11). Whether or not one approves of the answers, these are the questions to which nationalism addresses itself John Wilson argues that genuine religions exhibit five features that are absent from American civic piety. These are 1) cultic aspects, such as the provision for frequent ceremony and ritual, 2) recognized leadership offices invested with effective authority, 3) explicitly defined individual participation that establishes grounds for membership, 4) doctrines of correct belief, and 5) a coherence among these categories that makes the concept of religion applicable (John F Wilson, "The Status of 'Civil Religion' in America," The Religion of the Republic, ed by Elwyn A Smith Philadelphia Fortress Press, 1971 12). Nationalism supplies all these in abundance. Still, Kelly argues that the visible symbols "we would naturally attach to the common practice of a civil devotion have been more and more emptied of substance, commitment, and participation" (.Politics 237). It is hard to imagine that he could be thinking of the flag, imbued with symbolic substance as it is and commanding both commitment and participation.

"Whatever else civil religion is," he continues, "with its penchant for communicative symbols and collective memory, it is not an indicator of the self-sacrifice of individuals" (Politics 239). On the contrary, self-sacrifice is the central theme of an American civil religion of patriotism organized around the flag.

${ }^{8}$ The contrast between the ritual and sacrificial victim is also Girard's, though he has not applied it to contemporary nation-state violence

${ }^{9}$ Richard Hottelet, CBS war correspondent, interview in "CBS Reports D-Day," May 26, 1994

${ }^{10}$ Quoted in Bruce W Neland, "Ike's Invasion," Time, June 6, 199440 "See, for example, Carolyn Marvin, "Fresh Blood, Public Meal,"

Communication Research 21/3 (June, 1994) 264-292

\section{References}

Anderson, Benedict Imagined Communities Revised ed New York, Verso 1991

Eliade, Mircea Cosmos and History The Myth of the Eternal Return 2nd edition New York, Harper \& Row 1959

Giddens, Anthony The Nation-State and Violence Berkeley, University of California Press 1985

Girard, Rene Violence and the Sacred Trans by Patrick Gregory Baltimore, Johns Hopkins University Press 1977

Hayes, Carlton Essays On Nationalism New York, Macmillan 1926

Rappaport, Roy "The Obvious Aspects of Ritual" In The Ecology of Religion, 173-221 Berkeley, CA North Atlantic Books 1979

Zelinsky, Wilbur Nation into State The Shifting Symbolic Foundations of American Nationalism Chapel Hill, University of North Carolina Press 1988 
